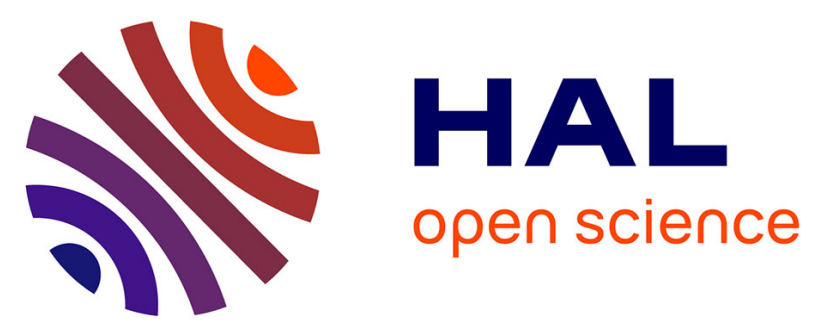

\title{
Late glacial and early Holocene hydroclimate variability in northwest Iran (Talesh Mountains) inferred from chironomid and pollen analysis
}

Cyril Aubert, Elodie Brisset, Morteza Djamali, Arash Sharifi, Philippe Ponel, Belinda Gambin, Tayebeh Akbari Azirani, Frédéric Guibal, Hamid Lahijani, Abdolmajid Naderi Beni, et al.

\section{To cite this version:}

Cyril Aubert, Elodie Brisset, Morteza Djamali, Arash Sharifi, Philippe Ponel, et al.. Late glacial and early Holocene hydroclimate variability in northwest Iran (Talesh Mountains) inferred from chironomid and pollen analysis. Journal of Paleolimnology, 2017, 58 (2), pp.151-167. 10.1007/s10933-017-9969-8 . hal-01681624

\section{HAL Id: hal-01681624 https://hal.science/hal-01681624}

Submitted on 19 Apr 2018

HAL is a multi-disciplinary open access archive for the deposit and dissemination of scientific research documents, whether they are published or not. The documents may come from teaching and research institutions in France or abroad, or from public or private research centers.
L'archive ouverte pluridisciplinaire HAL, est destinée au dépôt et à la diffusion de documents scientifiques de niveau recherche, publiés ou non, émanant des établissements d'enseignement et de recherche français ou étrangers, des laboratoires publics ou privés. 


\section{Late glacial and early Holocene hydroclimate variability in northwest Iran (Talesh Mountains) inferred from chironomid and pollen analysis}

Cyril Aubert ${ }^{1}$, Elodie Brisset ${ }^{1}$, Morteza Djamali ${ }^{1,2}$, Arash Sharifi ${ }^{3}$, Philippe Ponel ${ }^{1}$, Belinda Gambin ${ }^{4}$, Tayebeh Akbari Azirani ${ }^{5}$, Fréderic Guibal ${ }^{1}$, Hamid Lahijani ${ }^{2}$, Abdolmajid Naderi Beni ${ }^{2}$, JacquesLouis de Beaulieu ${ }^{1}$, Ali Pourmand ${ }^{3}$, Valérie Andrieu-Ponel ${ }^{1}$, Alain Thiéry ${ }^{1}$, Emmanuel Gandouin ${ }^{1}$

\begin{abstract}
We reconstructed the paleohydrologic and climatic history of the Lake Neor region, NW Iran, from the end of the late glacial to the middle Holocene (15,500-7500 cal yr BP). Subfossil chironomid and pollen assemblages in a sediment core from a peatland located south of Lake Neor enabled identification of four main hydrologic phases. The period 15,500-12,700 cal yr BP was characterized by a relatively dry climate with an open landscape, suggested by the abundance of Irano-Turanian steppe plants (e.g. Amaranthaceae, Artemisia and Cousinia). Dominance of several shallow-water and semi-terrestrial chironomid taxa (e.g. Pseudosmittia, Smittia / Parasmittia and Paraphaenocladius / Parametriocnemus) during this period is indicative of lower water
\end{abstract}

1. Aix-Marseille Univ, Avignon Universite', CNRS, IRD, IMBE, Technopole Arbois Mediterranee, Bat. Villemin, BP 80, 13545 Aix-En-Provence Cedex 04, France e-mail: cyril.aubert@imbe.fr

2. INIOAS: Iranian National Institute for Oceanography and Atmospheric Sciences, No. 3, Etemad Zadeh St., Fatemi Ave., 14155-4781, Tehran 1411813389, Iran

3. Department of Marine Geosciences, Rosenstiel School of Marine and Atmospheric Science, RSMAS/MGG, University of Miami, 4600 Rickenbacker Causeway, Miami, FL 33149, USA tables in the wetland. Between 12,700 and 11,300 cal yr $\mathrm{BP}$, chironomid taxa indicate higher wetland water tables, as suggested by the presence of Zavrelia, Chironomus anthracinus / plumosus-type and Micropsectra, which are inhabitants of open-water, lacustrine areas. The open-steppe vegetation remained dominant in the watershed during this time. Increasing wetland moisture could be explained by: (1) cool summers that reduced the evaporation rate; and/or (2) a decrease in duration of the summer dry season. The period 11,300-8700 cal yr BP was characterized by lower wetland moisture, contemporaneous with a delay in the expansion of deciduous forest, suggesting persistent dry climate conditions throughout the beginning of the Holocene, which may have been

\author{
4. B. Gambin \\ Institute of Earth Systems, University of Malta, \\ Msida, MSD 2080, Malta \\ 5. T. Akbari Azirani \\ Department of Geography, Shahid Beheshti University, \\ Tehran, Iran
}


related to the intensified seasonality of precipitation. Around $8700 \mathrm{cal}$ yr BP, higher wetland water levels, inferred from chironomids, occurred simultaneously with the onset of regional deciduous forest expansion, probably caused by a shortening of the summer dry period. We concluded that chironomids are appropriate paleoecological proxies to investigate global and local hydrologic variability in the Middle East.

Keywords

Climate change, Seasonality, Paleohydrology, IranoTouranian steppe, Lake Neor, Middle East

\section{Introduction}

The late glacial/early Holocene transition was a key period in Earth's history for understanding global environmental changes. Changes at that time led to the present configuration of ecosystems and to the beginning of the agricultural revolution and the formation of human civilizations (Lotter 2004). Environmental changes during this important transition are well documented for Europe (Roberts et al. 2011), but remain under-documented for the Middle East, which has a longer history of humanenvironment interactions. Indeed, significant impacts of human activities on Middle Eastern ecosystems may extend back to the early Holocene, or even the late glacial period, as suggested by the very early domestication of plants and animals in the region (Zeder and Hesse 2000; Riehl et al. 2013). Studies outside the Fertile Crescent, though not far from it, suggest that the onset of nomadopastoralism and transhumance in northwestern Iran may date back to $6500 \mathrm{cal}$ yr BP (Ponel et al. 2013). This latter region is the subject of the present paleoenvironmental study. Indeed, in northwestern Iran and eastern Turkey (Stevens et al. 2001; Djamali et al. 2008; Wasylikowa et al. 2006; Wick et al. 2003), as well as in the Caucasus region (Connor and Kvavadze 2009; Messager et al. 2013), the last glacial landscapes were open, with dry steppe vegetation. Better climate conditions during the late glacial Interstadial (LGI) enabled rapid expansion of pioneer trees. Nevertheless, this expansion remained limited and steppe vegetation continued to dominate the landscape, as shown by high percentages of Artemisia in regional pollen diagrams (Wick et al. 2003). Open landscapes were maintained up to ca. $9000-8000 \mathrm{cal} \mathrm{yr}$
BP (Messager et al. 2013). In Europe and western Mediterranean areas, thermal changes seem to have been the main control on plant growth and vegetation dynamics, whereas such changes seem to have been controlled more by moisture in the eastern Mediterranean, including NW Iran. Of particular interest is the long delay in postglacial forest expansion at the beginning of the Holocene (ElMoslimany 1987; Stevens et al. 2001; Roberts 2002; Djamali et al. 2010; Messager et al. 2013). This delay has been interpreted as an indication of stronger precipitation seasonality, based on biological and geochemical evidence reported by El-Moslimany (1987), Stevens et al. (2001, 2006), and Wick et al. (2003). These authors argued that the climate of the eastern Anatolian and western Iranian plateaus was relatively dry, possessing a typical Mediterranean climate with a winter-dominated precipitation regime until ca. 6500 cal yr BP. More recently, geochemical investigations of a sediment core taken from the littoral zone of a lake in the Talesh Mountains (Sharifi et al. 2015) provided a high-resolution record of past hydro-logical changes and regional atmospheric dust influx. Sharifi et al. (2015) inferred relatively dry climate conditions over NW Iran during the Younger Dryas (YD) based on $\mathrm{dD}$ values of $\mathrm{C}_{28} \mathrm{n}$-alkanoic acid, followed by a change in moisture source and seasonality of precipitation from the onset of the Holocene to $8000 \mathrm{cal}$ yr BP. A similar climatic pattern was observed in several lakes within the eastern Mediterranean, based on $\mathrm{d}^{18} \mathrm{O}$ analysis (Roberts et al. 2008, 2011).

Complex moisture variability in the Middle East has impacted human communities since the beginning of Neolithic times. In this regard, seasonality of climate might have affected the lifestyle of early Holocene human communities, through its impact on the timing of annual mobility of these communities (e.g. the transhumance). It definitely had an impact on the emergence of agriculture, because many early cultivars have strongly seasonal phenologies, e.g. barley and wheat (Zohary et al. 2012). Later, in the late Holocene, environmental changes may have impacted the socioeconomic and geopolitical evolution of the Middle East, as suggested by a number of authors, including Staubwasser and Weiss (2006) and Sharifi et al. (2015). In this complex climatic and anthropogenic historical context, understanding the late glacial/early Holocene transition is of great scientific interest, not only to better understand the local and regional variability in environmental change, but also 
to detect early large-scale anthropogenic versus climatic influences on the ecosystems.

We investigated hydrological and vegetation changes that occurred at Lake Neor in NW Iran (N 38L12 ${ }^{0}$ $32^{00}$; E $48 \mathrm{~L} 19^{0} 42^{00} ; 2480 \mathrm{~m}$ asl) from 15,500 to 7500 cal yr BP, using chironomid and pollen analysis (Fig. 1). For the first time, we used chironomids (Insect, Diptera) in a sediment record from Iran as a paleoecological proxy. Among paleoclimate proxy variables, chironomids have been used mainly as paleotemperature indicators (Heiri et al. 2011). They have also been used widely as indicators of past changes in lake water quality, since the classification of lake trophic state types established by Brundin (1956). Chironomids are also sensitive to many other environmental variables, including salinity changes (Eggermont et al. 2006; Zhang et al. 2007) and lake level fluctuations (Eggermont et al. 2007). They have also demonstrated their potential for use in detecting past human impacts (Ruiz et al. 2006). These characteristics make chironomids valuable paleoenvironmental proxies, independent of pollen and geochemical data.

This study aimed to:

1. document the utility of chironomids for inferring environmental factors such as water-table fluctuations and associated wetland moisture, presence and abundance of aquatic vegetation, eutrophication, etc.;

2. infer paleohydrological changes in Lake Neor during the late glacial and early Holocene, using chironomids;

3. compare these changes with pollen and geochemical analyses from the same record to describe the paleoenvironment more accurately;

4. place the paleoenvironmental evolution at Lake Neor in the framework of more regional climatic changes.

\section{Study area}

Lake Neor is located in the Talesh Mountains, a northsouth-trending high mountain range that separates the high Irano/Azerbaijan plateaus from the south Caspian plains (Fig. 1). This tectonic lake is about $4 \mathrm{~km}$ long and is bordered by [3000-m-high mountains, mostly composed of andesitic rocks (Madadi et al. 2005). Its maximum surface area of $* 2.2 \mathrm{~km}^{2}$ occurs during late winter and early spring, when its two sub-basins are united. Mean water depth is about $2 \mathrm{~m}$, with a maximum depth of $5.5 \mathrm{~m}$ in the southeastern corner of the lake. The lake surface area can be reduced by more than $50 \%$ during periods of low precipitation (Madadi et al. 2005), and aquatic conditions are thus ephemeral along the lake margins, with the littoral marsh environment often transformed into hydromorphic soils. Vast peat mires, hundreds of meters wide, extend along the southern margin of the lake (Fig. 1). The lake is located near the meso-thermophilous Hyrcanian forest (-26 to $* 2100 \mathrm{~m}$ asl); the latter owes its presence to orographic processes, which lead to an accumulation of humidity related to water evaporation from the Caspian Sea on the north slopes of the Alborz Mountains and east slopes of the Talesh Mountains (Khalili 1973; Akhani et al. 2010; Ponel et al. 2013). The Lake Neor area is located in a transitional zone, between the NW Iranian highlands with a Mediterranean-continental bioclimate, and the south Caspian region with a temperate oceanic bioclimate (Djamali et al. 2012).

The study area is influenced by three climate systems: the Mid-latitude Westerlies, Siberian Anticyclone, and Indian Ocean Summer Monsoon (IOSM). The main sources of moisture in the Lake Neor area are the Mediterranean and Black Seas, and moisture is brought to the region by the Mid-latitude Westerlies, with the reinforcement of the Siberian Anticyclone and/or a northward shift of the Intertropical Convergence Zone (ITCZ), which obstructs this moisture from reaching the region (Djamali et al. 2010). Precipitation falling as both rain and snow (Sharifi et al. 2015) is highest during spring (before May) and winter (after November). The lake does not receive water from any permanent river (Kazanc1 et al. 2016). The summer dry season lasts from July to October. Details on the physical setting, climate conditions and modern vegetation of Lake Neor are found in Ponel et al. (2013), Sharifi et al. (2015) and Kazancı et al. (2016).

\section{Materials and methods}

Coring, lithostratigraphy, radiocarbon dating, magnetic susceptibility and hydrogen isotope composition of precipitation

Coring was done using a Russian borer, enabling the retrieval of eight successive $1-\mathrm{m}$ core sections that are 7 $\mathrm{cm}$ in diameter. The maximum depth reached was 


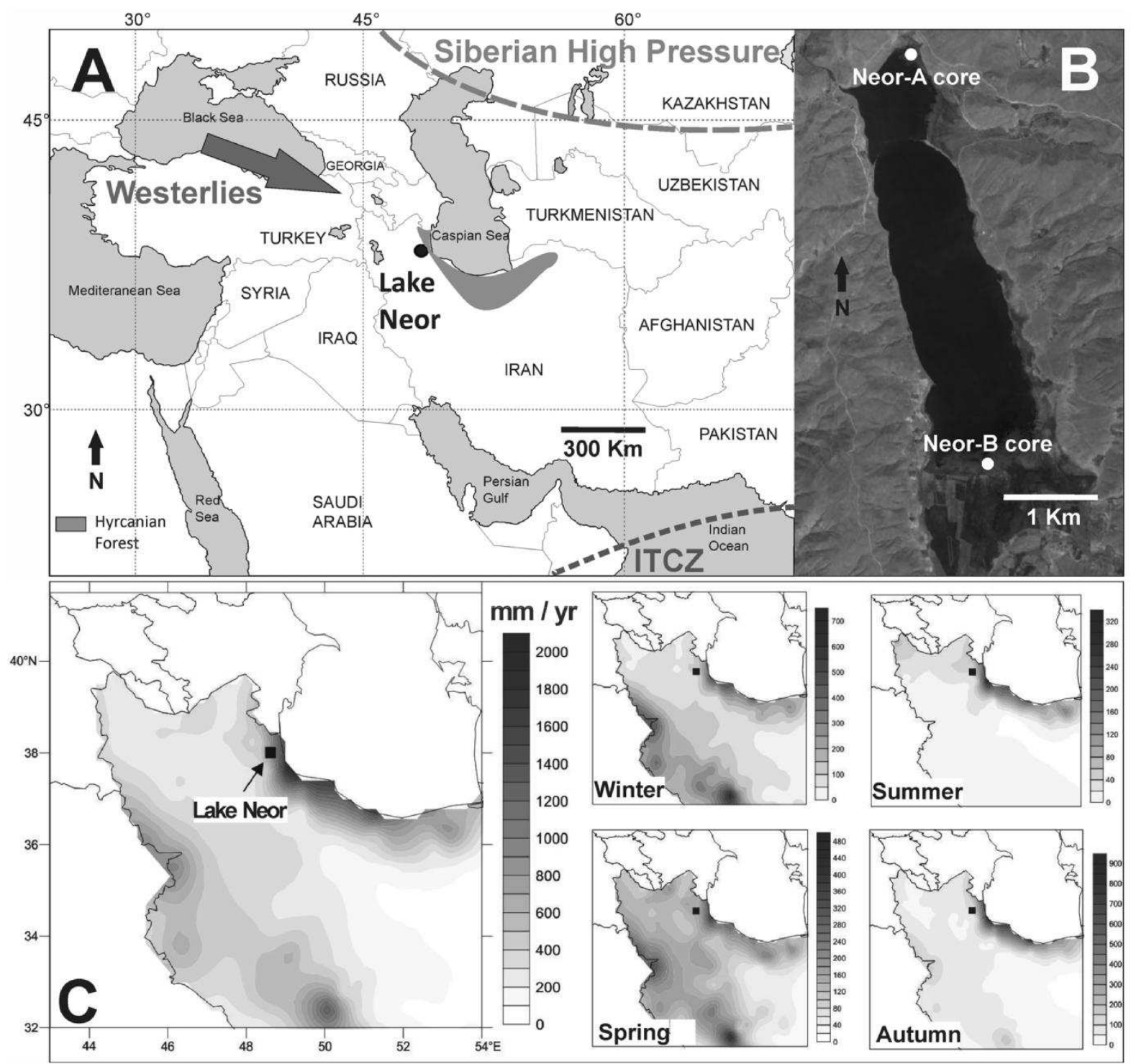

Fig. 1 a Map showing the location of Lake Neor in NW Iran. b Location of the Neor-B sediment core used in this study, and the Neor-A sediment core (Ponel et al. 2013). c Maps of annual

and seasonal precipitation over northwestern Iran. Data adapted from the Iran Meteorological Organization

$800 \mathrm{~cm}$. Magnetic susceptibility was measured in the laboratory using a Bartington Multisusceptibility MS2E1 device. From 800 to $600 \mathrm{~cm}$, five bulk sediment samples were dated at the Poznan Radiocarbon Laboratory using the AMS radiocarbon dating technique (Table 1). The radiocarbon ages were calibrated with the Intcal13 calibration curve (Reimer et al. 2013) using the Clam package (Blaauw 2010) included in $\mathrm{R}$ version 3.0.1 ( $\mathrm{R}$ Core Team 2012) at two standard deviations. The age-depth model was

developed using linear interpolation, taking into account the probability distribution of the calibrated ages (Fig. 2).

In this study, the hydrogen isotope composition (dD) of precipitation was used to help identify the source of moisture. Methodological details of $\mathrm{dD}$ measurements are found in Sharifi et al. (2015). In general, two main processes control the isotopic composition of precipitation: (1) the source of moisture and (2) the distance from the source to the target 
basin. Different precipitation sources have different isotopic signatures. With respect to distance, the farther water vapor travels from the main source, the more negative the $\mathrm{dD}$ of the source moisture becomes (Stevens et al. 2001; Sharifi et al. 2015).

\section{Chironomid and pollen analyses}

Sixteen sediment samples, weighing between 80 and $150 \mathrm{~g}$, were collected for chironomid analysis at 10$\mathrm{cm}$ intervals between 800 and $640 \mathrm{~cm}$ depth. Laboratory methods for extraction and identification of subfossil remains are described in Gandouin et al. (2005) and consisted of deflocculation with $\mathrm{KOH}$, rinsing with water over a $100-\mu \mathrm{m}$ sieve, and paraffin flotation. A minimum of 50 head capsules per sample was chosen to provide statistically significant estimates of environmental conditions (Heiri and Lotter 2001). Identification of head capsules was based on Brooks et al. (2007). Head capsules were identified under a stereomicroscope at 4009 magnification. Chironomid diagrams were drawn using C2 software version 1.7.2 (Juggins 2007).

The core was sub-sampled every $10 \mathrm{~cm}$ for pollen analysis. Samples were processed according to the classical extraction technique summarized in Moore et al. (1991). Pollen was identified using the reference collection of the Mediterranean Institute of Biodiversity and Ecology (IMBE), pollen atlases of Europe and Northern Africa (Reille 1995) and a description of pollen types of Western Iran (Van Zeist and Bottema 1977). At least 300 terrestrial pollen grains were counted in each sample to determine palynomorph concentration and relative abundance; pollen of aquatic plants, including the Cyperaceae, and spores were excluded from the total pollen sum. Pollen diagrams were drawn using TILIA version 1.5.12 (Grimm 1990).

Statistical analyses of biological subfossil data

A constrained sum-of-squares cluster analysis (CONISS) for percentage data was performed with TILIA version 1.5.12 to highlight major changes in chironomid and pollen assemblage composition throughout the stratigraphy (Grimm 1987). The classical procedure of validation of significant zones by the "broken-stick model" was inefficient here, because of the low number of samples (cf. the Ioannina data set analyzed by Bennett 1996). In such cases, only ecological zones based on evident cross-correlation between chironomid and pollen data can be considered.

Detrended Correspondence Analysis (DCA) and Principal Component Analysis (PCA) were performed using "ade4" and "vegan" packages in R software version 3.2.2 ( $R$ Core Team 2012) on the $n$ (number of samples) by $\mathrm{p}$ (number of taxa) chironomid matrix of percentages. Data were square root transformed to stabilize the variance. Rare taxa, i.e. those present in only one sample or with a relative abundance consistently $15 \%$, were removed from the analysis. To avoid possible bias related to core overlapping, samples from 695 and $705 \mathrm{~cm}$, at the extremes of the basal two core sections, were passively placed in the subfossil dataset, excluding them from the analysis. DCA sample scores reflect the relative position of each sample, characterized by a specific faunal assemblage, among all samples, in response to one or more ecological gradients. These scores give an estimate of the overall compositional change between
Table $1{ }^{14} \mathrm{C}$ ages on material from the Lake Neor core. Calibrated dates were obtained with the Clam package (Blaauw 2010) of $\mathrm{R}$ software version 3.0.1 (R Core Team 2012) and the non-marine (IntCal13) radiocarbon calibration curve (Reimer et al. 2013). Calibrated ages are reported at $2 \mathrm{r}$ ranges

\begin{tabular}{lllcc}
\hline Laboratory code & Depth $(\mathrm{cm})$ & Material & Age yr BP $\left({ }^{14} \mathrm{C}\right)$ & Age yr cal yr BP $(2 \mathrm{r}$ interval $)$ \\
\hline Poz-54054 & 602.5 & Peaty gyttja & $5285 \pm 35$ & $6074(5987-6182)$ \\
Poz-54055 & 652.5 & Peaty gyttja & $7290 \pm 40$ & $8058(8019-8176)$ \\
Poz-54056 & 702.5 & Dark gyttja & $9300 \pm 50$ & $10,489(10,369-10,602)$ \\
Poz-54057 & 752.5 & Brown gyttja & $10,630 \pm 60$ & $12,569(12,516-12,682)$ \\
Poz-54058 & 777.5 & Brown gyttja & $12,300 \pm 60$ & $14,309(13,965-14,636)$ \\
Poz-27625 & 798 & Wood (Salix root $)$ & $12,270 \quad \pm 70$ & $14,259(13,902-14,605)$ \\
\hline
\end{tabular}


Fig. 2 Lithostratigraphy and age-depth model for the Neor-B core. The age-depth model was developed with the CLAM software (Blaauw 2010) using a linear-interpolated method and the "IntCal13", ${ }^{14} \mathrm{C}$ calibration curve (Reimer et al. 2013). The deepest radiocarbon date was obtained on a root fragment of Salix and is considered too young. This age was treated as an outlier and discarded in the age-depth model

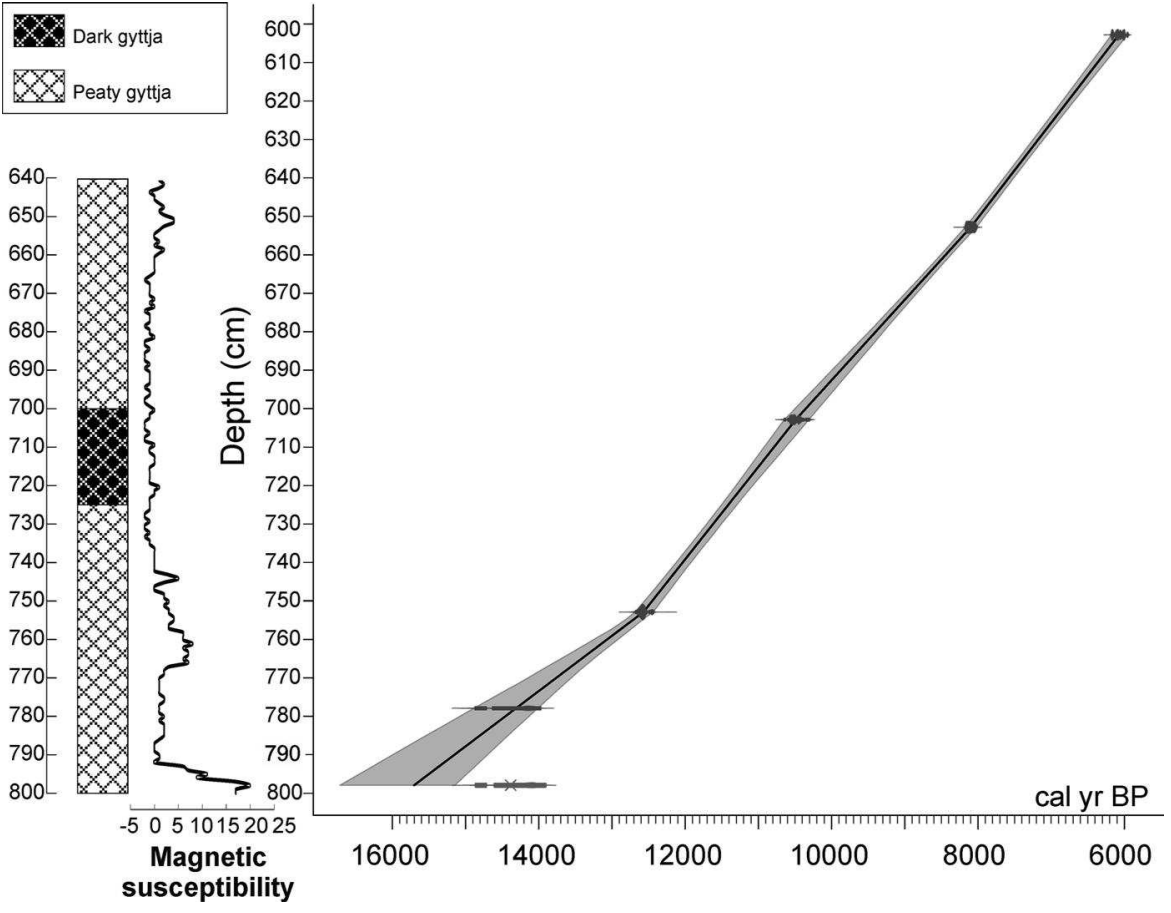

was removed from the age model. The sample was identified as a root of Salix sp., which explains its young age relative to surrounding sediments. The peak of Salix pollen at $790 \mathrm{~cm}$, above the depth of this wood sample (Fig. 5), further suggests that the wood fragment originated from a later tree/shrub stand.

Magnetic susceptibility of the sediment is characterized by a sharp decrease (from 20 to $0910^{5}$ SI units) at the bottom of the core, between 800 and 790 $\mathrm{cm}$ (Fig. 2). The magnetic susceptibility is relatively low from $790 \mathrm{~cm}$ to the top of the core, except from 765 to $750 \mathrm{~cm}$ and from 660 to $640 \mathrm{~cm}$, where slight increases are observed. The hydrogen isotope composition (dD) of precipitation at Lake Neor ranges from -186 to -225 per mil (Fig. 6).

\section{Chironomid analysis}

Thirty-one chironomid taxa were identified from 1046 head capsules. PCA (Figs. 3, 4) was performed on a data matrix of 22 taxa for 16 samples. The PCA axis 1 $(\mathrm{k} 1=0.270)$ shows a clear contrast between two groups of taxa (Fig. 4). The first group (positive side) is mainly characterized by Pseudosmittia, Smittia/Parasmittia and Cladotanytarsus mancus-type 1 . The second group (negative side) is characterized by Zavrelia, "too-old" ages on bulk sediment. The "Poz-27625" sample (Table 1), which consisted of subfossil wood, 
Limnophyes/Paralimnophyes, Paratendipes nudisquama-type, Heterotrissocladius grimshawi-type and Polypedilum nubeculosum-type. The negative side of the PCA axis $2(\mathrm{k} 2=0.180)$ is characterized by a third group composed of Chironomus anthracinus-type, Chironomus plumosus-type, Cricotopus and Neozavrelia. The positive side is characterized by Parametriocnemus/Paraphaenocladius, Polypedilum nubeculosumtype, Micropsectra and Gymnometriocnemus/ Bryophaenocladius. According to the CONISS classification (Fig. 3), a first level of hierarchy is observed at about $750 \mathrm{~cm}$. The variations of characteristic taxa of the PCA axis 1 (e.g. Cladotanytarsus mancus-type 1 and Smittia/Parasmittia) explain the first level of hierarchy in the CONISS classification. The chironomid record can be divided into four zones:

$\mathrm{Nch} 1=800-750 \mathrm{~cm}, \mathrm{Nch} 2=750-720 \mathrm{~cm}, \mathrm{Nch} 3=$ $720-670 \mathrm{~cm}$, and Nch4 $=670-640 \mathrm{~cm}$ based on the faunal assemblages.

Zone Nch1 is characterized by strong dominance of Smittia/Parasmittia and Parametriocnemus/Paraphaenocladius and substantial abundance of Cladotanytarsus mancus-type 1. The PCA axis 1 score values are minimal during this zone (Fig. 3). The second zone, Nch2, is marked by an increase of Zavrelia, Polypedilum nubeculosum-type, Chirono-mus anthracinus-type and Limnophyes/Paralimno-phyes (Fig. 3). The PCA axis 1 score values increase throughout the zone and attain their first maximum at $735 \mathrm{~cm}$. Zone Nch3 shows a decrease in percentages of Zavrelia, Polypedilum nubeculosum-type, Limnophyes/Paralimnophyes, Chironomus anthracinus-type, and Parametriocnemus/Paraphaenocladius, while abundances of Micropsectra, Pseudorthocla-dius, and Cricotopus increase. The PCA axis 1 scores are slightly negative during the first part of Nch3, then increase at the end of the zone. The onset of the zone is also marked by maximum abundances of Limoniidae larvae. The last zone, Nch4, is characterized by an increase in percentages of Zavrelia, Limnophyes/ Paralimnophyes, Chironomus anthracinus, Chirono-mus plumosus and Glyptotendipes pallens-type, which all reach their highest abundances at the end of the zone (Fig. 3). Percentages of Parametriocnemus/ Paraphaenocladius are relatively stable in zones $\mathrm{Nch} 3$ and $\mathrm{Nch} 4$, whereas Smittia/Parasmittia and

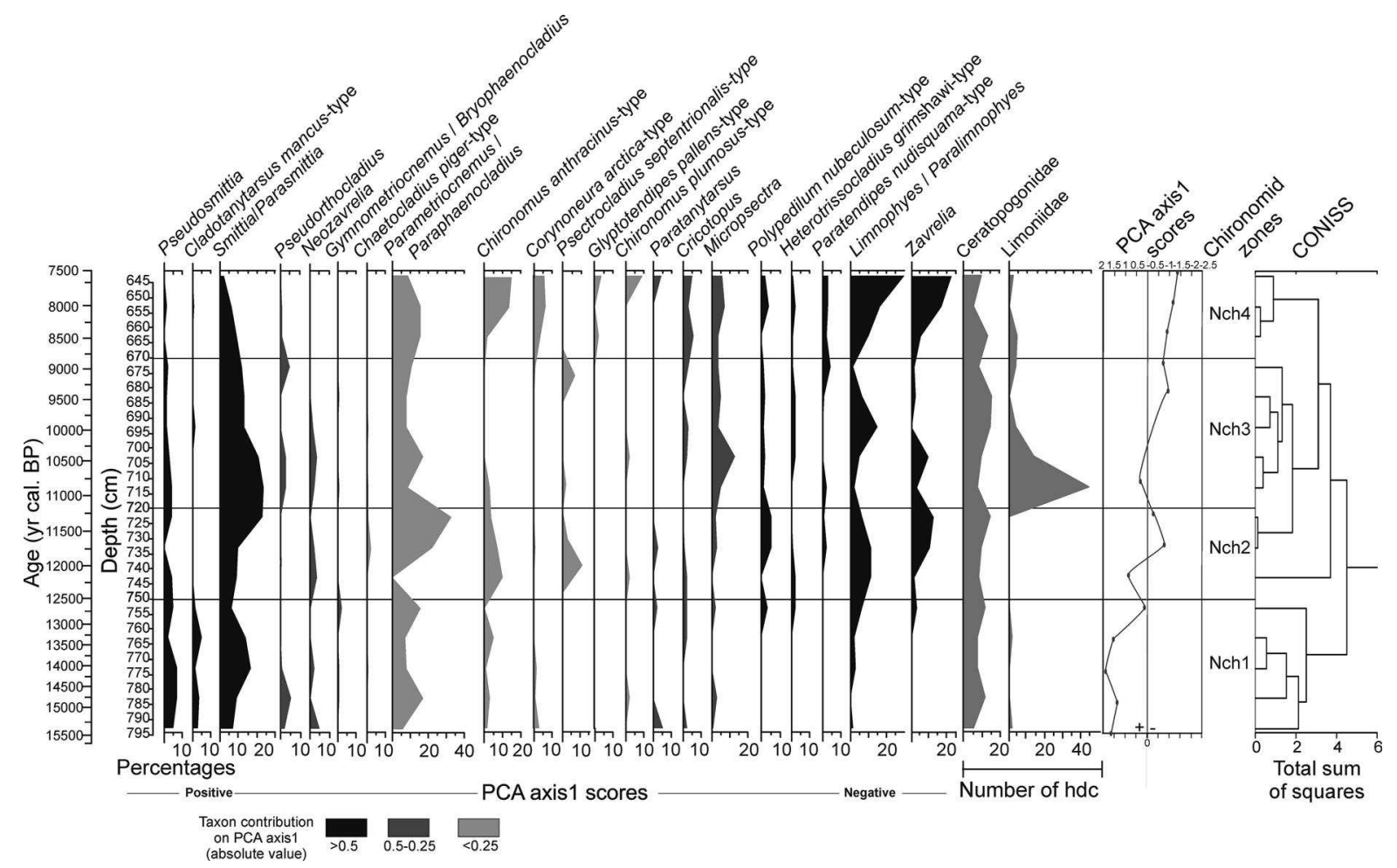

Fig. 3 Subfossil chironomid diagram from the Neor-B core. Zonation was accomplished by depth-constrained cluster analysis (CONISS). Nch1-4: chironomid zones. Taxa are ranked according to their PCA axis 1 contribution from positive to negative 


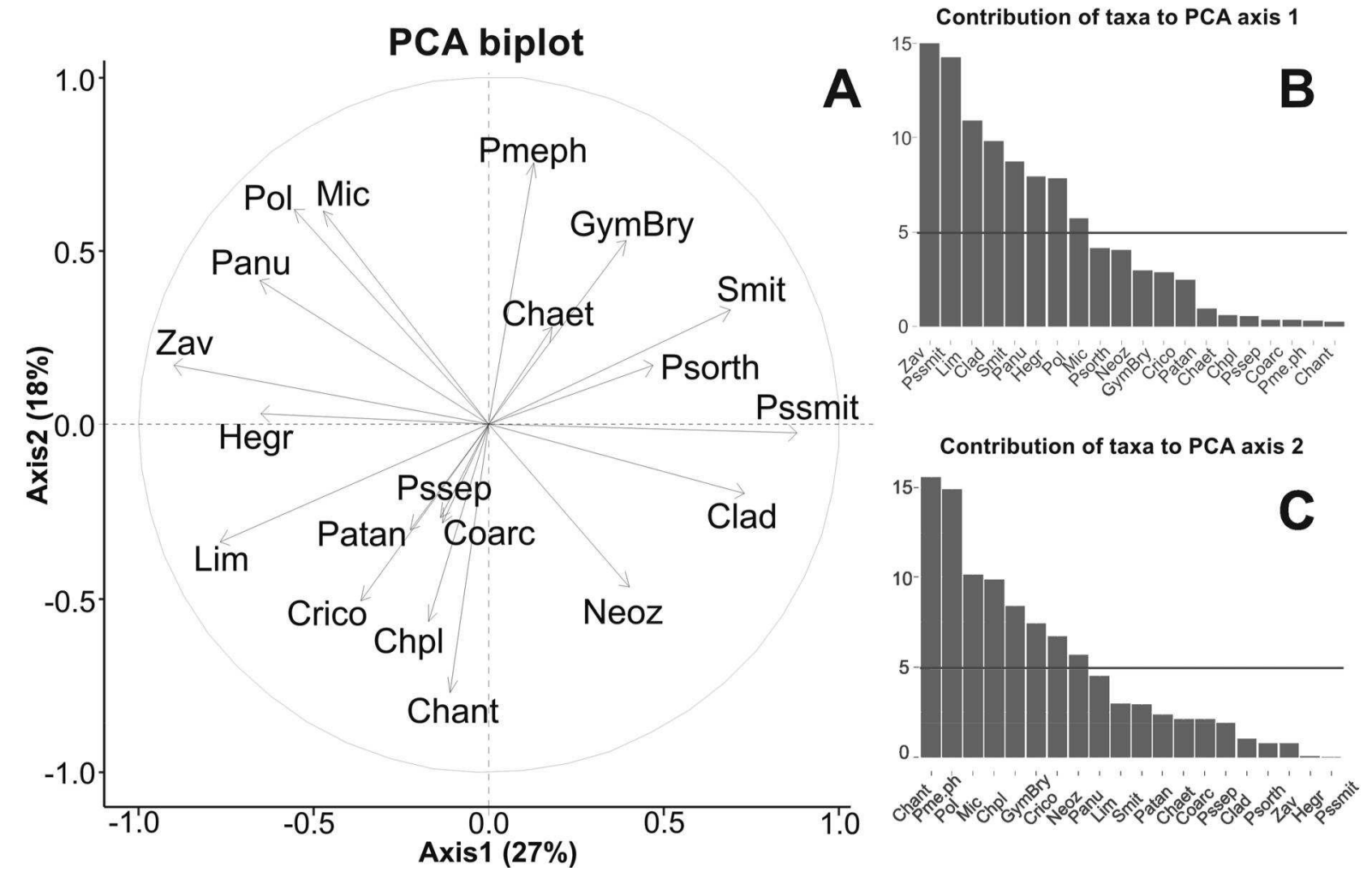

Fig. 4 Statistical analyses on chironomid data. a PCA results. b Taxon contributions to the first PCA axis (in absolute value). The main contributing taxa are above the horizontal line (at $y=5$ ). c Taxon contributions to the second PCA axis (in absolute value). The main contributing taxa are above the horizontal line (at y = 5). Taxa code-Neoz: Neozavrelia; Coarc: Corynoneura arctica-type; Mic: Micropsectra; Pol:

Polypedilum nubeculosum-type; Chant: Chironomus anthracinus-type; Chpl: Chironomus plumosus-type; Zav: Zavrelia;

Pseudosmittia percentages decrease from the beginning of zone Nch4.

\section{Pollen analysis}

Cyperaceae is the dominant pollen taxon throughout the sequence, probably because of the presence of an extensive peatland on the lake margins. According to the CONISS classification (Fig. 5), a first level of hierarchy is observed at about $750 \mathrm{~cm}$ (Fig. 5). This shift is explained by an increase in percentages of arboreal taxa such as Quercus and Betula, as well as Poaceae, at the expense of steppe taxa, particularly Amaranthaceae and Caryophyllaceae. Based on vegetation dynamics, five zones were defined: $\mathrm{Np} 1=800-775 \mathrm{~cm} ; \mathrm{Np} 2=775-752 \mathrm{~cm}$;
Clad: Cladotanytarsus mancus-type 1; Panu: Paratendipes nudisquama-type; Limno: Limnophyes/Paralimnophyes; Pmeph: Parametriocnemus/Paraphaenocladius; Pssmit: Pseudosmittia; Smit: Smittia/Parasmittia; GymBry: Gymnometriocnemus/Bryophaenocladius; Hegr: Heterotrissocladius grimshawi-type; Psorth: Pseudorthocladius; Chaet: Chaetocladius piger-type; Crico: Cricotopus; Pssep: Psectrocladius septentrionalis-type; Patan:

Paratanytarsus

$\mathrm{Np} 3=752-725 \mathrm{~cm} ; \mathrm{Np} 4=725-665 \mathrm{~cm} ; \mathrm{Np} 5=665-$ $640 \mathrm{~cm}$.

Zone Np1 is characterized by the scarcity of trees and dominance of Iranian-Turanian mountain dry steppe plants such as Amaranthaceae and Artemisia, which increase progressively over the zone. In $\mathrm{Np} 1$, Salix reaches its maximum, probably related to the expansion of a cold-adapted species similar to boreal species Salix herbacea L. Local presence of Salix is confirmed by its macrorests (roots) in the basal part of the sequence. During zone $\mathrm{Np} 2$, the Iranian-Turanian steppe taxa reach their maximum expansion and pollen of Cousinia appear in the assemblages. This period is also marked by a decrease in Cyperaceae pollen percentages. The submersed aquatic taxon 


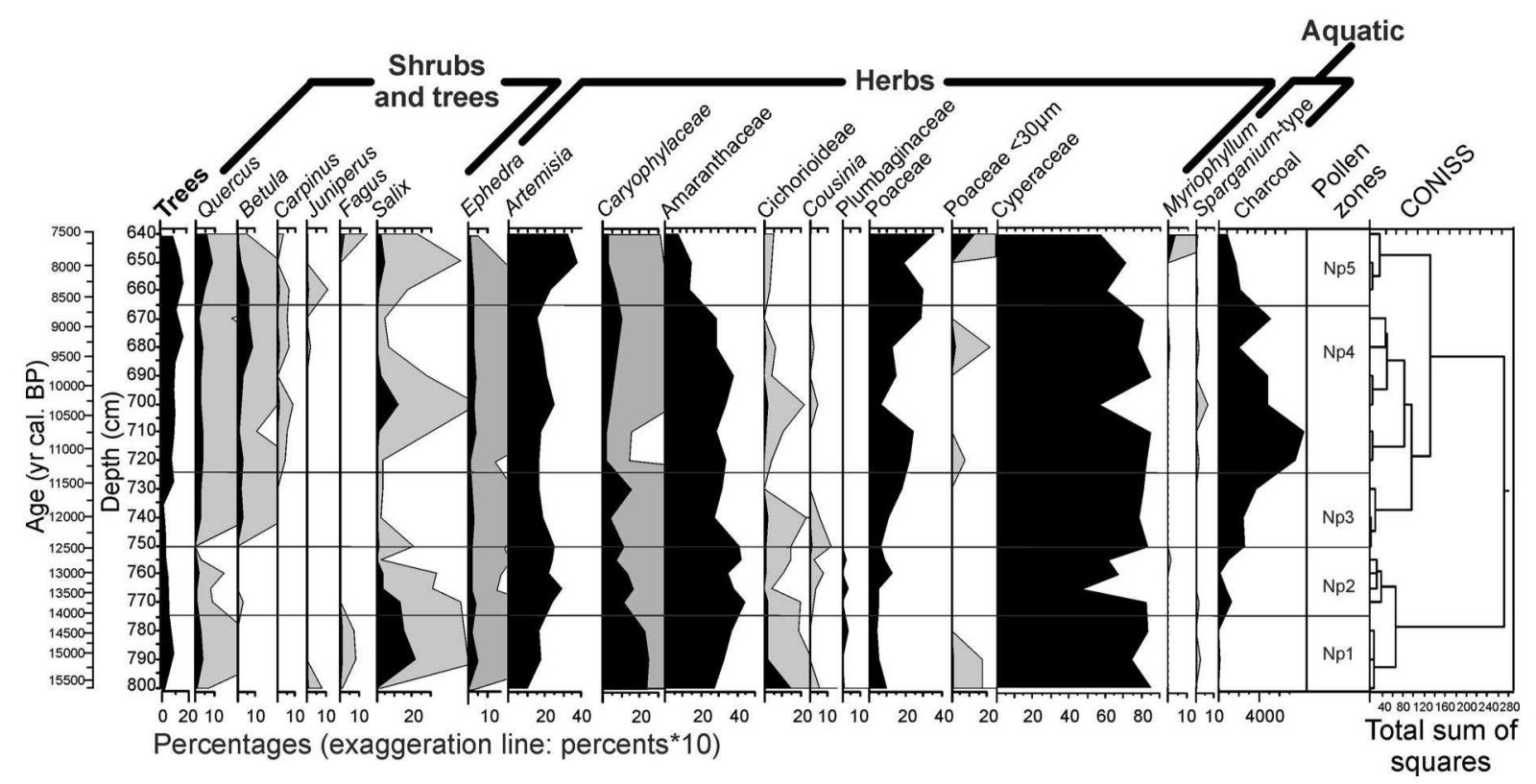

Fig. 5 Summary pollen diagram from the Neor-B record. Zonation was accomplished by depth-constrained cluster analysis (CONISS). Np1-5: pollen zones

Myriophyllum appears for the first time during this zone, albeit with low values. Larger amounts of Myriophyllum pollen, at the expense of Cyperaceae, suggest higher lake levels and more permanent lacustrine conditions. Zone Np3 is marked by a slight increase in Quercus and Betula relative abundance. This rise in tree abundance continues in zone $\mathrm{Np} 4$, which is characterized by the appearance of Carpinus, though the abundance of this latter taxon remains low. During Np3 and later $\mathrm{Np} 4$, increases in Cyperaceae and Poaceae may be related to the re-establishment of an extensive peatland. The microcharcoal curve reaches its maximum values during the first part of zone $\mathrm{Np} 4$. The percentages of Cyperaceae decrease temporarily at 695 $\mathrm{cm}$, while Salix percentages reach their second maximum. At the end of zone Np4, Amaranthaceae percentages start to decrease, while Juniperus increases. Lastly, zone Np5 is characterized by a new increase in percentages of tree taxa, during which Quercus and especially Fagus gradually replace pioneers such as Betula and Juniperus. Overall, this zone is marked by taxonomic diversification of both terrestrial and aquatic vegetation.

\section{Discussion}

Ecological significance of chironomids in the Lake Neor record

Table 2 summarizes the ecological interpretation of the main chironomid taxa and assemblages found in Lake Neor based on the available literature. In general, the main chironomids of the Neor sediment record are characteristic of shallow lacustrine conditions, with large seasonal water table fluctuations. Presence of aquatic macroinvertebrates of the Limoniidae and Ceratopogonidae (Fig. 3), in association with several semi-terrestrial chironomids, reinforces the above interpretation. Moreover, the existence of several taxa associated with macrophytes (e.g. Pseudosmittia, Orthocladius and Cricotopus), suggests the presence of a well-developed macrophytic belt on the lake margins. Some of the main taxa, such as Gymnometriocnemus/Bryophaenocladius and Parametriocnemus/ Paraphaenocladius, can be indicative of very shallow water, but also of stream inflows and changes in catchment erosion. This hypothesis is in agreement 
Table 2 Summarized ecology of main chironomid and related insect taxa in Lake Neor

\begin{tabular}{|c|c|}
\hline Taxon & Ecology \\
\hline Smittia/Parasmittia & $\begin{array}{l}\text { Generally known as terrestrial or semi-terrestrial (Strenzke 1950; Cranston et al. 1983). May also be } \\
\text { found in aquatic environments such as littoral zones (Cranston et al. 1983; Brooks et al. 2007) }\end{array}$ \\
\hline $\begin{array}{l}\text { Gymnometriocnemus/ } \\
\text { Bryophaenocladius }\end{array}$ & $\begin{array}{l}\text { Generally known as terrestrial or semi-terrestrial (Strenzke 1950; Cranston et al. 1983) Can been } \\
\text { found living in woodland soils (Cranston et al. 1983), their presence may also be related to detrital } \\
\text { inputs (Brooks et al. 2007) }\end{array}$ \\
\hline Pseudosmittia & $\begin{array}{l}\text { Generally known as terrestrial or semi-terrestrial (Cranston et al. 1983; Strenzke 1950). May also be } \\
\text { found in aquatic environments such as in the littoral zones (Cranston et al. 1983; Brooks et al. } \\
\text { 2007). Is also associated with aquatic macrophytes (Brodin 1986) }\end{array}$ \\
\hline $\begin{array}{l}\text { Parametriocnemus/ } \\
\text { Paraphaenocladius }\end{array}$ & $\begin{array}{l}\text { Generally known as terrestrial or semi-terrestrial (Strenzke 1950; Cranston et al. 1983). Can also } \\
\text { occur in streams and occasionally in littoral zones of lakes (Moog 2002) }\end{array}$ \\
\hline $\begin{array}{l}\text { Cladotanytarsus mancus-type } \\
1\end{array}$ & $\begin{array}{l}\text { Has been associated with littoral zone of warm and productive lakes (Brundin 1949; Sæther 1979; } \\
\text { Brodin 1986) and can tolerate acidic conditions (Brodin 1986; Utala 1986). Is typical of lentic } \\
\text { water bodies (Gandouin et al. 2006) having low connectivity with main channels and in ephemeral } \\
\text { ponds (Karaus 2004) }\end{array}$ \\
\hline $\begin{array}{l}\text { Chironomus } \\
\text { anthracinus/plumosus-type }\end{array}$ & $\begin{array}{l}\text { Commonly confined to deeper parts of lakes, they can also be tolerant of hypoxic to anoxic waters } \\
\text { (Brooks et al. 2007; Zhang et al. 2012), and to low values of pH (Brodin 1986) and high salinity } \\
\text { (Vallenduuk and Moller Pillot 2002). Engels and Cwynar (2011) reported the presence of these } \\
\text { taxa in circum-neutral aquatic environment in northeast USA }\end{array}$ \\
\hline Zavrelia & $\begin{array}{l}\text { A typical taxon of temperate eutrophic lakes (Brundin 1949; Walker et al. 1991). Z. pentatoma has a } \\
\text { widespread distribution in the eastern Palearctic region (Sæther and Spies 2004). Z. pentatoma is } \\
\text { found in or near peat pits, moor ponds and moor lakes rich in humic acids and with relatively low } \\
\text { pH (Brundin 1949; Ekrem and Stur 2009) }\end{array}$ \\
\hline $\begin{array}{l}\text { Paratendipes nudisquama- } \\
\text { type }\end{array}$ & $\begin{array}{l}\text { An inhabitant of littoral zones of mesotrophic lakes (Sæther 1979; Brodin 1986) and also occurs in } \\
\text { running waters (Pinder and Reiss 1983) }\end{array}$ \\
\hline $\begin{array}{l}\text { Polypedilum nubeculosum- } \\
\text { type }\end{array}$ & $\begin{array}{l}\text { Usually lives in the littoral zones of eutrophic lakes in temperate regions (Hofmann 1984; Brodin } \\
\text { 1986). Some species of the genus live amongst vegetation (Brodersen et al. 2001) }\end{array}$ \\
\hline Glyptotendipes pallens-type & $\begin{array}{l}\text { An inhabitant of mesotrophic to eutrophic lakes. This taxon is also known to be acidophilic (Brodin } \\
\text { 1986) }\end{array}$ \\
\hline Micropsectra & $\begin{array}{l}\text { Several species of the genus have a wide ecological tolerance and live in both oligotrophic and } \\
\text { mesotrophic lakes (Brodin 1986; Brooks et al. 2007). It has also been reported in ephemeral lakes } \\
\text { and ponds (Brooks et al. 2007) }\end{array}$ \\
\hline Cricotopus/Orthocladius & $\begin{array}{l}\text { Eurytopic and found in both flowing and standing waters. These two genera are practically } \\
\text { ubiquitous in lake sediments (Brooks et al. 2007) and are often associated with aquatic vegetation } \\
\text { (Brodin 1986; Sæther 1979) }\end{array}$ \\
\hline Paratanytarsus & $\begin{array}{l}\text { Has a large range of temperature tolerance, may be abundant in warm or cold lakes (Brooks et al. } \\
\text { 2007). They are often associated with macrophytes (Brodin 1986) }\end{array}$ \\
\hline Corynoneura arctica-type & $\begin{array}{l}\text { Taxa abundant in alpine/arctic lakes as well as warmer lakes (Brooks et al. 2007). They live in } \\
\text { littoral zones of lakes, often in association with macrophytes (Brodin 1986; Brodersen et al. 2001) }\end{array}$ \\
\hline Limnophyes/Paralimnophyes & $\begin{array}{l}\text { Live in various habitats, but always found in shallow water in the littoral zones of lakes (Kansanen, } \\
\text { 1985). The genus can indicate lake level fluctuation (Massaferro and Brooks 2002). Some species } \\
\text { are associated with aquatic macrophytes (Brodin 1986), whereas others are terrestrial and semi- } \\
\text { terrestrial (Cranston et al. 1983). Many species of the genus have been reported in dynamic } \\
\text { environments and can be considered as a taxon with successive generations that move from one } \\
\text { place to another to reach damper areas (Delettre 1986) }\end{array}$ \\
\hline Ceratopogonidae & $\begin{array}{l}\text { Larvae of most species are commonly found in shallow water and ephemeral aquatic environments } \\
\text { (Nilsson 1997) }\end{array}$ \\
\hline Limoniidae & $\begin{array}{l}\text { Larvae are found in various semi-aquatic environments during most of their development and move } \\
\text { to the lake margins or drier places to pupate (Nilsson 1997) }\end{array}$ \\
\hline
\end{tabular}


with the current presence of modest alluvial fans (*700 to $400 \mathrm{~m}$ long) on the eastern slopes of the watershed. Nevertheless, the influence of rivers and springs, and the role of catchment erosion on the Neor chironomid assemblages, may be minimal or negligible for three reasons:

1. Neor Lake has a small catchment $\left(45 \mathrm{~km}^{2}\right)$ with no large fluvial input and fairly level topography (Kazanc1 et al. 2016), which should minimize the rate of natural erosion;

2. the coring site is located between the present-day lake shore and the large peat bog south of the lake, the latter acting as a buffer zone that traps fluvial input that could contain riverine chironomid head capsules;

3. geochemical data also indicate a lack of fluvial sedimentation. Study of inorganic fine particle sediment layers in the Neor peat profile indicates significant correlations between the representative immobile (Ti), redox-sensitive (Fe) and mobile (Rb) elements (Fe vs. Ti, r = 0.90; Rb vs. Ti, r = 0.92). Wavelet semblance analyses between refractory conservative elements $(\mathrm{Ti}, \mathrm{Zr}, \mathrm{Si}, \mathrm{Al})$ and both mobile $(\mathrm{Rb})$ and redox-sensitive $(\mathrm{Fe})$ elements show significant correlations among these element pairs through the entire record (Sharifi et al. 2015).

The evidence not only confirms that the fine particles have not been mobilized since deposition, but also indicates that these particles are introduced to the lacustrine environment predominantly by one means of transport, i.e. through atmospheric deposition.

Chironomids along the wetland moisture gradient: implications with respect to water table fluctuations

The dominant ecological groups bring together those taxa that have the most weight on PCA axis 1 (Fig. 4): on one hand, terrestrial and semi-terrestrial taxa having affinity to ephemeral and marginal lake wetlands (Pseudosmittia, Smittia/Parasmittia), and on the other hand, taxa typical of more permanent water bodies, such as Zavrelia, Paratendipes nudisquama-type, Heterotrissocladius grimshawi-type and Polypedilum nubeculosum-type (Table 2). This suggests that PCA axis 1 represents a moisture gradient, from open-water to shallow wetland conditions (marshes, wet meadows and hydromorphic soils).

Concerning Limnophyes/Paralimnophyes, these taxa usually inhabit shallow water as well as semi-terrestrial environments (Table 2). This broad ecological tolerance probably reflects the fact that this group includes more than one, and perhaps several species (Saether 1975; Delettre 1986). In addition, this group has been reported in very dynamic aquatic environments and, thus, has to be considered opportunistic (Table 2). As a consequence, ecological interpretation based on this group must be done cautiously, especially without other faunal evidence. At Neor, Limnophyes/Paralimnophyes is associated with the group of taxa typical of more permanent water bodies (Fig. 4), on the negative side of the PCA axis 1.

Regarding PCA axis 2 and the third faunal group (negative side), Langdon et al. (2010) showed that taxa such as Chironomus sp., Cricotopus and Glyptotendipes pallens-type can be dominant in shallow lakes with low plant species richness, turbid waters and high levels of both total phosphorus (TP) and chlorophyll-a. This positive relationship between detritivores (Chironomini) and planktonic primary productivity, in the form of chlorophyll-a, may indicate the presence of pelagic open waters. These species are thus logically opposite, on PCA axis 2, to taxa (positive side) that inhabit the lake margin environments, such as Parametriocnemus/Paraphaenocladius and Gymnometriocnemus/Bryophaenocladius (Brooks et al. 2007), but also to taxa such as Polypedilum nubeculosum-type and Micropsectra. Indeed, P. nubeculosum-type is indicative of relatively clear water with variable macrophyte density and/or plant species richness (Langdon et al. 2010). Don-caster et al. (2016) showed the disappearance of P. nubeculosum-type during major deterioration of water quality, most probably caused by increasing TP concentrations. Micropsectra sp. are also sensitive to such eutrophication, as suggested by Armitage et al. (1995), based on study of a Swedish lake. Using these ecological data, PCA axis 2 may thus be interpreted as a water eutrophication gradient linked to both TP and chlorophyll-a concentrations, water turbidity and the presence of macrophytes.

We suggest that PCA axis 1 characterizes a gradient of persistence of open-water conditions, whereas PCA axis 2 represents a gradient of increased density and/or the extension of macrophyte vegetation. The PCA axis 
1 gradient should be related to seasonal changes in wetland hydrology. Indeed, it is very likely that the main environmental factor that determines the chironomid faunal composition illustrated by PCA axis 1 is seasonal alternation of flooding (winter) and drying (summer) of the wetland, i.e. seasonal water table fluctuation. Higher precipitation in late spring may reduce the length of the summer drought, and thus extend the period of permanent aquatic conditions, before the open water is transformed to shallow marsh later in the summer, which probably increases moisture at the lake margins and in surrounding hydromorphic soils. The topography of the site could also play a role in aquatic zone expansion (Engels et al. 2016) and therefore also influence chironomid distribution, however our results do not provide enough information to elaborate on this point.

Paleoenvironmental at Lake Neor in a regional context

15,500-12,500 cal yr BP (cf. zones Nch1/Np1 and $\mathrm{Np2}$ ): dry climate conditions

The beginning of the Lake Neor record is character-ized by higher frequencies of Irano-Turanian steppe plants such as Amaranthaceae and Artemisia (Np1, Fig. 5), typical of an open landscape on the surrounding slopes of the lake, accompanied by maximum expansion of riparian woody vegetation (characterized by Salix) over the peatlands. Under the conditions of a sparsely vegetated catchment, the slopes were sensitive to erosion, as suggested by the highest values of magnetic susceptibility (Fig. 2). This period is also characterized by the highest positive scores of PCA axis 1 (Fig. 3) on the chironomid data, suggesting seasonal drying of the lake margin, favorable to the establishment of terrestrial and semi-terrestrial chironomid taxa such as Pseudosmittia, Gymnometriocnemus / Bryophaenocladius, Smittia/Parasmittia and Pseudorthocladius. Besides, abundances of Cladotanytarsus mancus-type 1, a taxon usually found in the littoral zones of temperate (Brooks et al. 2007), tropical African (Eggermont et al. 2007) and Asian (Nazarova et al. 2011; Zhang et al. 2012) lakes might reflect more saline water conditions (Zhang et al. 2012). Low percentages of Corynoneura arctica-type, Cricotopus and Paratanytarsus could suggest low development of aquatic macrophytes (Brooks et al.
2007). High percentages of Neozavrelia suggest relatively cold climate conditions (Brooks et al. 2007). In the absence of data on temperature-representativeness of Iranian chironomids, however, such a thermal interpretation is proposed with due caution. Indeed, the ecological tolerance of $\mathrm{C}$. arctica-type is wide (Brooks et al. 2007). Altogether, these results suggest that the beginning of the Lake Neor record was characterized by a continental climate, associated with a lower water table in the wetland, probably subject to intense summer drought. Based on geochemical data from Lake Neor, Sharifi et al. $(2015)$ also inferred a relatively dry climate between 13,500 and 12,500 cal yr BP, evidenced by high dust influx (Fig. 6).

El-Moslimany (1987) highlighted driest climate conditions from $16,000 \mathrm{cal}$ yr BP $(13,650 \pm 160 \mathrm{BP})$ to before 13,400 cal yr BP $(11,480 \pm 160 \mathrm{BP})$ at Lake Zeribar (northwestern Iran), based on the Amaranthaceae/Artemisia ratio. In the Zeribar record, it was demonstrated that high abundances of Amaranthaceae and Artemisia should not be interpreted only as a signal of aridity, but also as a signal of strengthened seasonality (El-Moslimany 1987), therefore a long summer drought that limited the growth of forest trees. This is also the case for the Caucasus region (Connor and Kvavadze 2009).

\section{2,500-11,300 cal yr BP (cf. zones Nch2/Np3):}

a change in precipitation seasonality?

The increase of Cousinia pollen percentages, associated with the rising abundances of Artemisia, suggests an open landscape over the Neor watershed starting during Np2 and continuing during Np3 (Fig. 5). Cousinia, a taxon adapted to cold and to high levels of continentality, is well represented in the last glacial records from both northwestern Iran and eastern Anatolia (Djamali et al. 2012). The presence of this taxon could indicate cold and dry regional climate conditions. This period is also marked by a pronounced decrease in pollen of both Cyperaceae and Salix, suggesting a probable regression of the peatlands and riparian woody stands. This regression is contemporaneous with negative PCA axis 1 scores for chironomid data (Fig. 3), which may indicate longer permanent aquatic conditions on the lake margins, caused by higher water tables. 


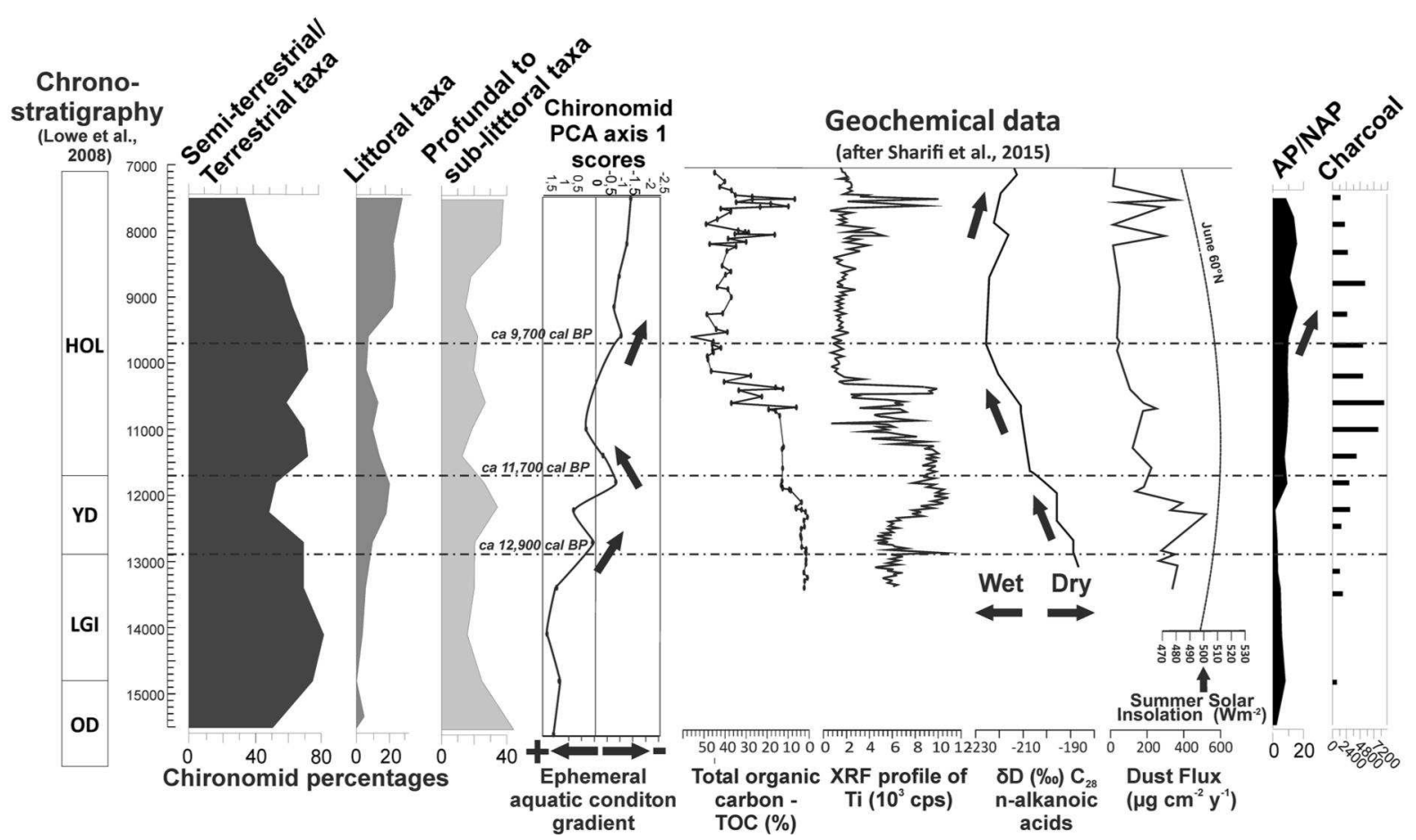

Fig. 6 Synthetic diagram for multi-proxy data from Neor Lake after Sharifi et al. (2015). OD: Older Dryas. LGI: Late glacial Interstadial. YD: Younger Dryas. HOL: Holocene

According to Sharifi et al. (2015), dust fluxes were maximal around 12,300 cal yr BP (Fig. 6), when open land, exposed to eolian erosion, extended over large areas of the northern Eurasian continent. As high-lighted by Sharifi et al. (2015), however, this period was also marked by a progressive increase in regional atmospheric moisture in southwestern Asia. This is consistent with the higher moisture of the lake margins, suggested by chironomids, and might be a sign of a decrease in evaporation, related to cooler summer temperatures and/or lower seasonality of precipitation. Such a decrease in lacustrine evaporation was observed by Cagatay et al. (2014) in Lake Van during the same time period.

\section{1,300 to ca. 8700 cal yr BP (cf. zones Nch3/Np4):} a prolonged summer drought?

The onset of this period was characterized by the presence of Quercus and the appearance of Betula (Fig. 5). The weakness of this signal, however, raises the question of whether this reflects local or regional presence of these trees. Nowadays, the Hyrcanian forest east of Lake Neor is mainly composed of
Quercus castaneifolia and Carpinus betulus, from low to middle elevations. These two taxa are mesophilous and sensitive to summer drought (Akhani et al. 2010; Djamali et al. 2011). Low representation of these taxa in the pollen diagram can be explained by two hypotheses: (1) absence of these taxa in the vicinity of the lake and long-distance transport of their pollen from the lowerelevation coastal plains and foothills around the Caspian Sea. Upward pollen transport is probably facilitated by prevailing winds coming from the Caspian Sea (Khalili 1973); (2) longer summer droughts. The latter hypothesis is partly confirmed by lower wetland moisture levels, given by positive PCA axis 1 scores during the first part of Nch3 (Fig. 3). High abundances of aquatic macroinvertebrates adapted to hydromorphic soil conditions (Fig. 3) can also reflect a change in seasonality of precipitation, responsible for drier conditions along the lake margins during summer. We note that the hypothesis of Sharifi et al. (2015), suggesting an early Holocene increase in regional humidity (Fig. 6), might not be contrary to our results, if we consider changes in the seasonality of precipitation. Indeed, changes in the seasonality of precipitation can have the same effect on lake levels as 
a general increase or decrease in annual precipitation (Stevens et al. 2001). Lastly, the decrease in the wetland moisture could also be explained by: (1) higher evaporation rates related to stronger summer insolation (Fig. 6) and (2) higher summer temperatures and/or higher evapotranspiration rates linked to the development of riparian tree stands.

A dominant arid phase at the onset of the Holocene (ca. 11,600 cal yr BP) has already been detected at many locations throughout the continental Middle East and southern Mediterranean (Wasylikowa et al. 2006; Djamali et al. 2010; Leroy et al. 2013; Kaplan 2013). At Lake Neor, the microcharcoal peak observed at ca. 10,600 cal yr BP is also in agreement with the hypothesis of pronounced seasonality, which leads to a long dry season prone to fire propagation in the grasslands and grass-dominated steppes. Similar charcoal peaks are also observed at several other sites in the continental Middle East (Van Zeist and Bottema 1977; Wick et al. 2003). Alternatively, fires could also be related to early Neolithization of the Middle East (Roberts 2002). Anthropogenic clearing of the forests and scrublands for cereal cultivation and pastures could have favored the maintenance of Irano-Turanian grass steppes. Nevertheless, at Lake Neor, palynological data do not show signs of early human activity in the watershed.

8700-7500 cal yr BP (cf. zones Nch4/Np5): a more humid spring and summer?

Sharifi et al. (2015) proposed that increasing regional atmospheric moisture marked the early Holocene, reaching a maximum between 9500 and $8500 \mathrm{cal} \mathrm{yr} \mathrm{BP}$ (Fig. 6). This period corresponds to the onset of the rise in wetland moisture, as suggested by PCA axis 1 scores of the chironomid data from Lake Neor (Fig. 6). This is also contemporaneous with a slight increase in the arboreal/non-arboreal pollen ratio and the rise in Quercus and Fagus percentages during Np5. The appearance of Myriophyllum (Fig. 5), a sub-mersed aquatic plant, indicates the establishment of a more permanent lacustrine system, with a significant area of open water surrounded by stands of shallow freshwater marshes with reeds (Sparganium, Typha, and probably Phragmites). That inference is accentuated by high percentages of Corynoneura arctica-type, Cricotopus and Paratanytarsus (Brooks et al. 2007). The maximal values of Zavrelia, Chironomus anthracinus-type and Chironomus plumosus-type at the top of the sequence also suggest more open-water conditions (Brooks et al. 2007). These latter conditions could be partly explained by lower summer insolation, thereby inducing lower evaporation (Fig. 6), and a contemporaneous rise in regional atmospheric humidity, as observed in most paleoenvironmental records from the Middle East (Wasylikowa et al. 2006; Fleitmann et al. 2007; Djamali et al. 2010). This climate change allowed the establishment and diversification of the deciduous forest, as was observed at Lake Paravani in Georgia (Messager et al. 2013). Diversification of the forest began later in southern Zeribar and Lake Mirabad (Iran) around $6500 \mathrm{cal} \mathrm{yr} \mathrm{BP} \mathrm{(Stevens} \mathrm{et} \mathrm{al.} \mathrm{2001,} \mathrm{2006;}$ Djamali et al. 2010). These differences could be linked to the higher latitudinal setting of Lake Neor and the Caucasian lakes, which could have then been more affected by Ponto-Caspian microclimate conditions that provided more moisture to these regions.

\section{Conclusions}

For the first time, chironomids were used in a multiproxy paleoenvironmental study in Iran, providing new valuable information on late glacial and early Holocene hydroclimate changes. Because of a lack of ecological information on both subfossil and modern Iranian chironomid taxa, however, paleolimnological inferences were undertaken with caution. At this stage, comparisons to known ecological preferences of equivalent chironomid taxa in Europe, Africa, and other parts of the Middle East are required.

Nevertheless, chironomid assemblages effectively reflect variations in wetland moisture in Neor, and are interpreted here as a proxy for seasonal changes in moisture availability, especially changes in lake water balance linked to winter/spring precipitation and snow melt, and evaporation during summer months. Our chironomid results compared with other biological and physico-chemical variables in the Lake Neor sediments revealed a succession of different hydro-climate phases between 15,500 and $7500 \mathrm{cal} \mathrm{yr} \mathrm{BP.}$

The time interval between ca. 15,500 and 12,500 cal yr BP was probably dry, maintaining ephemeral lake conditions at Neor, a situation that re-occurred to a lesser extent during the interval ca. $11,300-8700$ cal yr BP. The interval ca. 
$12,900-11,700$ cal yr BP was marked by more permanent lacustrine conditions, probably caused by a change in seasonality of precipitation. Lastly, the time period ca. $8700-7500$ cal yr BP was characterized by increasing moisture over the wetland, contemporaneous with the establishment of deciduous forests on the mid-elevation, drained slopes.

The strong seasonality during the early Holocene, proposed by several authors based on pollen and geochemical proxies, is well corroborated by our study, suggesting that chironomid assemblages are informative and promising hydro-climatic indicators for paleoenvironmental reconstructions in the semiarid regions of the World, especially when they are compared with pollen and geochemical analyses. Indeed, chironomids appear to be good indicators of both lacustrine conditions and the peripheral expansion of terrestrial habitats related to summer drought. Chironomids are thus a promising proxy for future investigations of local and regional hydrological changes in semi-arid regions of the World.

Acknowledgements This project was supported by the FrancoGerman ANR/DFG project entitled "PALEO-PERSEPOLIS'" (ANR-14-CE35-0026-01) and the European ERC project entitled "PERSIA." The authors thank the former director of the Iranian National Institute for Oceanography and Atmospheric Sciences, Dr Vahid Chegini for his support of our paleoenvironmental studies in NW Iran. Thanks are also due to SJ Brooks, S Engels and an anonymous reviewer for their help, which improved this manuscript.

\section{References}

Akhani H, Djamali M, Ghorbanalizadeh A, Ramezani E (2010) Plant biodiversity of Hyrcanian relict forests, N Iran: an overview of the flora, vegetation, paleoecology and con-servation. Pak $\mathrm{J}$ Bot 42:231-258

Armitage PD, Pinder LC, Cranston P (1995) The Chironomidae: biology and ecology of non-biting midges. Springer, New York, p 572

Bennett KD (1996) Determination of the number of zones in a biostratigraphical sequence. New Phytol 132:155-170 Blaauw M (2010) Methods and code for 'classical' age-modelling of radiocarbon sequences. Quat Geochronol 5:512518

Brodersen KP, Odgaard BV, Vesteraard O, Anderson NJ (2001) Chironomid stratigraphy in the shallow and eutrophic Lake Søbygaard, Denmark: chironomidmacrophyte co-occur-rence. Freshw Biol 46:253-267

Brodin YW (1986) The postglacial history of Lake Flarken, southern Sweden, interpreted from subfossil insect remains. Int Rev Gesamten Hydrobiol 71(371):432
Brooks SJ, Langdon, PG, Heiri O (2007) The Identification and Use of Palaeartic Chironomidae Larvae in Palaeoecology. Technical Guide N810. Quaternary Research Association, London

Brundin L (1949) Chironomiden und andere Bodentiere der su"dschwedischen Urgebirgseen. Ein Beitrag zur Kenntnis der bodenfaunistischen Charakterzu"ge schwedischer oligotropher Seen. Report of the Institute of Freshwater Research, Drottningholm 30:1-914

Brundin L (1956) Zur Systematik der Orthocladiinae (Dipt., Chironomidae). Report of the Institute of Freshwater Research, Drottningholm 37:5-185

C, agatay MN, Ogretmen M, Damci E, Stockhecke M, Sancar U, Eris KK, Ozeren S (2014) Lake level and climate records of the last $90 \mathrm{ka}$ from the Northern Basin of Lake Van, eastern Turkey. Quat Sci Rev 104:97-116

Chen J, Zhang E, Brooks SJ, Huang X, Wang H, Liu J, Chen F (2014) Relationships between chironomids and water depth in Bosten Lake, Xinjiang, northwest China. J Paleolimnol 51:313-323

Connor SE, Kvavadze EV (2009) Modelling late Quaternary changes in plant distribution, vegetation and climate using pollen data from Georgia, Caucasus. J Biogeogr 36:529-545

Cranston PS, Oliver DR, Sather OA (1983) The larvae of the Orthocladiinae (Diptera: Chironomidae) of the Holarctic region. Keys and diagnoses. Entomol Scand Suppl 19:149-291

Delettre Y (1986) La colonisation de biotopes multiples: une alternative a' la re'sistance in situ aux conditions me'sologiques de'favorables, Cas de Limnophyes minimus (Mg.) Dipte re Chironomide', larves e'daphiques des landes armoricaines. Rev Ecol Biol Sol 23:29-38

Djamali M, De Beaulieu J-L, Shah-hosseini M, Andrieu-Ponel V, Ponel P, Amini A, Akhani H, Leroy SAG, Stevens L, Lahijani H, Brewer S (2008) A late Pleistocene long pollen record from Lake Urmia, NW Iran. Quat Res 69:413-420

Djamali M, Akhani H, Andrieu-Ponel V, Braconnot P, Brewer S, Beaulieu J-L, Fleitmann D, Fleury J, Gasse F, Guibal F, Jackson ST, Le'zine A-M, Me'dail F, Ponel P, Roberts N, Stevens L (2010) Indian Summer Monsoon variations could have affected the early-Holocene woodland expansion in the Near East. Holocene 20:813-820

Djamali M, Akhani H, Khoshravesh R, Andrieu-Ponel V, Ponel P, Brewer S (2011) Application of the Global Bioclimatic Classification to Iran: implications for understanding the modern vegetation and biogeography. Ecol Mediterr 37:91-114

Djamali M, Baumel A, Brewerb S, Jackson ST, Kadereit JW, Lo'pez-Vinyallonga S, Mehregan I, Shabanian E, Simakova A (2012) Ecological implications of Cousinia Cass. (Asteraceae) persistence through the last two glacial-interglacial cycles in the continental Middle East for the IranoTuranian flora. Rev Palaeobot Palyno 172:10-20

Doncaster CP, Chavez VA, Viguier C, Wang R, Zhang E, Dong X, Dearing JA, Langdon PG, Dyke JG (2016) Early warming of critical transitions in biodiversity from compositional disorder. Ecology 97:3079-3090

Eggermont H, Heiri O, Verschuren D (2006) Fossil Chironomidae (Insecta: Diptera) as quantitative indicators of past salinity in African lakes. Quat Sci Rev 25:1966-1994 
Eggermont H, De Deyne P, Verschuren D (2007) Spatial variability of chironomid death assemblages in the surface sediments of a fluctuating tropical lake (Lake Naivasha, Kenya). J Paleolimnol 38:309-328

Ekrem T and Stur E (2009) Zavrelia hudsoni recognized by Systema Dipterorum working record, Systema Dipterorum in the Catalogue of Life in The Catalogue of Life Part-nership: Catalogue of Life

El-Moslimany AP (1987) The late Pleistocene climates of the Lake Zeribar region (Kurdistan, Western Iran) deduced from the ecology and pollen production of nonarboreal vegetation. Vegetatio 72:131-139

Engels S, Cwynar LC (2011) Changes in fossil chironomid remains along a depth gradient: evidence for common faunal thresholds within lakes. Hydrobiologia 665:15-38 Engels S,

Brauer A, Buddelmeijer N, Martin-Puertas C, Rach O, Sachse D, Van Geel B (2016) Subdecadal-scale vegetation responses to a previously unknown late-Allerød climate fluctuation and Younger Dryas cooling at Lake Meerfelder Maar (Germany). J Quat Sci 31:741-752

Fleitmann D, Burns SJ, Mangini A, Mudelsee M, Kramers J, Villa I, Neff U, Al-Subarry A, Buettner A, Hippler D, Matter A (2007) Holocene ITCZ and Indian monsoon dynamics recorded in stalagmites from Oman and Yemen (Socotra). Quat Sci Rev 26:170-188

Gandouin E, Franquet E, Van Vliet-Lanoe B (2005) Chironomids (Diptera) in river floodplains: their status and potential use for palaeoenvironmental reconstruction purposes. Archiv fu"r Hydrobiologie 162:511-534

Gandouin E, Maasri A, Var Vliet-Lanoe“ B, Franquet E (2006) Chironomid (Insecta; Diptera) assemblages from a gradient of lotic and lentic waterbodies in river foodplains of France: a methodological tool for palaeoecological appli-cations. J Paleolimnol 35:149-166

Grimm EC (1987) CONISS: A FORTRAN 77 program for stratigraphically constrained cluster analysis by the method of incremental sum of squares. Comput Geosci 13:13-35

Grimm EC (1990) TILIA and TILIA.GRAPH: PC spreadsheet and graphics software for pollen data. INQUA Commission for the Study of the Holocene Working Group on Data Handling Methods 01/1990. Newsl 4:5-7

Heiri O, Lotter AF (2001) Effect of low count sums on quantitative environmental reconstructions: an example using subfossil chironomids. J Paleolimnol 26:343-350

Heiri O, Brooks SJ, Birks HJB, Lotter AF (2011) A 274-lake calibration dataset and inference model for chironomidbased summer temperature reconstruction in Europe. Quat Sci Rev 30:3445-3456

Hofmann W (1984) Stratigraphie subfossiler Cladocera (Crustacea) und Chironomidae (Diptera) in zwei Sedimentprofilen des Meerfelder Maares. Courier Forschungs Institut Senckenberg 65:67-80

Juggins S (2007) C2 Version 1.5 User guide. Software for ecological and palaeoecological data analysis and visualisation. NewcastleUniversity, Newcastle upon Tyne, UK

Kansanen PH (1985) Assessment of pollution history from recent sediments in Lake Vanajavesi, southern Finland. II. Changes in Chironomidae, Chaoboridae and Ceratopogo-nidae (Diptera) fauna. Ann Zool Fenn 22:57-90

Kaplan G (2013) Palynological analysis of the Late Pleistocene terrace deposits of Lake Van, eastern Turkey:
Reconstruction of paleovegetation and paleoclimate. Quat Int 292:168-175

Karaus U (2004) The ecology of lateral aquatic habitats along rivers corridor. Phd thesis. University of Heidelberg

Kazanc1 N, Gulbabazadeh T, Leroy SAG, Ataselim Z, Gu“rbu"lz A (2016) Aeolian control on the deposition of high altitude lacustrine basins in the Middle East: the case of Lake Neor, NW Iran. Quat Internat 408:65-77

Khalili A (1973) Precipitation patterns in central Alborz. Arch Meteor Geophys B 21:215-232

Langdon P, Ruiz Z, Wynne S, Sayer C, Davidson T (2010) Ecological influences on larval chironomid communities in shallow lakes: implications for palaeolimnological inter-pretations. Freshw Biol 55:531-545

Leroy SAG, Tudryn A, Chalie' F, Lo'pez-Merino L, Gasse F (2013) From the Allerød to the mid-Holocene: palynological evidence from the south basin of the Caspian Sea. Quat Sci Rev 78:77-97

Lotter AF (2004) Multi-proxy climatic reconstructions. In: Mackay AW, Battarbee RW, Birks HJB, Oldfield F (eds) Global change in the Holocene. Arnold Publisher, London, pp 371-383

Madadi A, Moghaddam MHR, Rajaei AH (2005) Study of the geomorphological evolution of the Neor Lake in Ardabil region, NW Iran. Quat J Georg Res 19:92-103 (in Persian)

Massaferro J, Brooks SJ (2002) The response of chironomids to Late Quaternary climate change in the Taitao Peninsula, southern Chile. J Quat Sci 17:101-111

Messager E, Belmecheri S, von Grafenstein U, Nomade S, Ollivier V, Voinchet P, Puaud S, Courtin-Nomade A, Guillou H, Mgeladze A, Dumoulin JP, Mazuy A, Lordkipanidze D (2013) Late Quaternary record of the vegetation and catchment-related changes from Lake Paravani (Javakheti, South Caucasus). Quat Sci Rev 77:125-140

Moog O (2002) Fauna Aquatica Austriaca, Edition 2002. Wasserwirtschaftskataster, Bundesministerium für Land-und Forstwirtschaft, Umwelt und Wasserwirtschaft, Vienna

Moore PD, Webb JA, Collinson ME (1991) Pollen analysis. Blackwell Scientific Publications, Oxford, p 216

Nazarova L, Herzschuh U, Wetterich S, Kumke T, Pestryakova L (2011) Chironomid-based inference models for esti-mating mean July air temperature and water depth from lakes in Yakutia, northeastern Russia. J Paleolimnol 45:57-71

Nilsson A (1997) Aquatic Insects of North Europe. A taxonomic Handbook. Volume 2. Odonata-Diptera. Appolo Books Aps, Stenstrup

Pinder LCV, Reiss F (1983) The larvae of Chironominae (Diptera: Chironomidae) of the Holartic region. Keys and diagnoses. Entomol Scand Suppl 19:293-435

Ponel P, Andrieu-Ponel V, Djamali M, Lahijani H, Leydet M, Mashkour M (2013) Fossil beetles as possible evidence for transhumance during the middle and late Holocene in the high mountains of Talysch (Talesh) in NW Iran? J Environ Archeol 3:201-210

R Core Team (2012) R: A language and environment for statistical computing. R Foundation for Statistical Computing, Vienna

Reille M (1995) Pollen et spores d'Europe et d'Afrique du Nord. Laboratoire de Botanique Historique et Palynologie, Marseille, Marseille, p 584 
Reimer PJ, Bard E, Bayliss A, Beck J-W, Blackwell PG, Ramsey CB, Buck CE, Cheng H, Edwards LR, Friedrich M, Grootes PM, Guilderson TP, Haflidason H, Hajdas I, Hatte' C, Heaton TJ, Hoffmann DL, Hogg AG, Hughen KA, Kaiser K-F, Kromer B, Manning SW, Niu M, Reimer RW, Richards DA, Scott E-M, Southon JR, Staff RA, Turney CSM, Van der Plicht J (2013) Intcal13 and Marine13 radiocarbon age calibration curves $0-50,000$ years CalBP. Radiocarbon 55:1869-1887

Riehl S, Zeidi M, Conard NJ (2013) Emergence of agriculture in the foothills of the Zagros Mountains of Iran. Science 341:65-67

Roberts N (2002) Did prehistoric landscape management retard the post-glacial spread of woodland in Southwest Asia? Antiquity 76:1002-1010

Roberts N, Jones MD, Benkaddour A, Eastwood WJ, Filippi ML, Frogley MR, Lamb HF, Leng MJ, Reed JM, Stein M, Stevens L, Valero-Garces B, Zanchetta G (2008) Stable isotope records of Late Quaternary climate and hydrology from Mediterranean lakes: the ISOMED synthesis. Quaternary Sci Rev 27:2426-2441

Roberts N, Eastwood WJ, Kuzucuog lu C, Fiorentino G, Caracuta V (2011) Climatic, vegetation and cultural change in the eastern Mediterranean during the mid-Holocene environmental transition. Holocene 21:147-162

Ruiz Z, Brown AG, Langdon PG (2006) The potential of chironomid (Insecta: Diptera) larvae in archaeological investigations of floodplain and lake settlements. J Archaeol Sci 33:14-33

Saether OA (1975) Twelve new species of Limnophyes Eaton, with keys to Nearctic males of the genus (Diptera: Chironomidae). Can Entomol 107:1029-1056

Sæther OA (1979) Chironomid communities as water quality indicators. Holarctic Ecol 2:65-74

Sæther OA, Spies M (2004) Chironomidae. In: de Jong H (ed) Fauna Europaea: Diptera, Nematocera. Fauna Europaea version 1.1, http://faunaeur.org

Sharifi A, Pourmand A, Canuel AE, Ferer-Tyler E, Peterson LC, Aichner B, Feakins SJ, Daryaee T, Djamali M, Naderi Beni A, Lahijani HAK, Swart PK (2015) Abrupt climate vari-ability since the last deglaciation based on a high-resolu-tion, multi-proxy peat record from NW Iran: The hand that rocked the Cradle of Civilization? Quaternary Sci Rev 123:215-230

Staubwasser M, Weiss H (2006) Holocene climate and cultural evolution in late prehistoric-early historic West Asia. Quat Res 66:372-387
Stevens LR, Wright HE Jr, Ito E (2001) Proposed changes in seasonality of climate during the Lateglacial and Holocene at Lake Zeribar, Iran. Holocene 11:747-755

Stevens LR, Ito E, Schwalb A, Wright HE Jr (2006) Timing of atmospheric precipitation in the Zagros Mountains inferred from a multi-proxy record from Lake Mirabad, Iran. Quat Res 66:494-500

Strenzke K (1950) Systematik, Morphologie und Okologie der terrestrischen Chironomiden. Arch Hydrobiol Suppl 18:207-214

Utala AJ (1986) Paleolimnological assessment of the effects of lake acidification on Chironomidae (Diptera) assemblages in the Adirondack region of New York. Phd thesis. State University of New York College of Environmental Science and Forestry, Syracuse, NY

Vallenduuk HJ, Moller Pillot HKM (2002) Key to the larvae of Chironomus in Western Europe. (revised edition, with separated index). Schijndel

Van Zeist W, Bottema S (1977) Palynological investigation in Western Iran. Palaeohistoria 19:19-85

Walker IR, Smol JP, Engstrom DR, Birks HJB (1991) An assessment of Chironomidae as quantitative indicators of past climate change. Can J Fish Aquat Sci 48:975-987

Wasylikowa K, Witkowski A, Walanus A, Hutorowicz A, Alexandrowicz SW, Langer JJ (2006) Palaeolimnology of Lake Zeribar, Iran, and its climatic implications. Quat Res 66:477-493

Wick L, Lemcke G, Sturm M (2003) Evidence of Lateglacial and Holocene climatic change and human impact in eastern Anatolia: high-resolution pollen, charcoal, isotopic and geochemical records from the laminated sediments of Lake Van, Turkey. Holocene 13:665-675

Zeder MA, Hesse B (2000) The initial domestication of goats (Capra hircus) in the Zagros Mountains 10,000 years ago. Science 287:2254-2257

Zhang E, Jones R, Bedford A, Langdon P, Tang H (2007) A chironomid-based salinity inference model from lakes on the Tibetan Plateau. J Paleolimnol 38:477-491

Zhang E, Zheng B, Cao Y, Gao G, Shen J (2012) Influence of environmental parameters on the distribution of subfossil chironomids in surface sediments of Bosten Lake (Xinjiang, China). J Limnol 71:291-298

Zohary D, Hopf M, Weiss E (2012) Domestication of plants in the Old World, 4th edn. Clarendon Press, Oxford 